\title{
Favorable Taste Ratings for Several Pawpaw Products
}

\author{
Susan B. Templeton, ${ }^{1}$ Martha Marlette, ${ }^{1}$ Kirk W. Pomper, ${ }^{2}$ and Snake C. Jones ${ }^{2}$
}

Additional INDeX words. Asimina triloba, kentucky banana, indiana banana

Summary. Marketed as a fresh fruit, the pawpaw (Asimina triloba) has a short shelf life, only 2-3 days at room temperature and up to 3 weeks with refrigeration. There is commercial processing potential for pawpaw pulp in juices, ice cream, yogurt, baked goods, and other products. Consumer acceptability of such products needs to be investigated. One hundred and five attendees of the $2^{\text {nd }}$ Annual Pawpaw Field Day at Kentucky State University (KSU), Frankfort, Ky., participated in a tasting of pawpaw products; $56 \%$ of tasters were male; $76 \%$ were over 40 years of age; $72 \%$ of tasters had eaten pawpaw previously. Each item was rated on a scale from $1=$ liked it extremely to $7=$ disliked it extremely. Pawpaw ice cream was the best-received item ( $55 \%$ of tasters liked it extremely), followed by pawpaw cake with lemon icing, liked extremely by $45 \%$. The pawpaw/grape juice drink was liked extremely by $31 \%$ of participants. Three alternative recipes for pawpaw butter were presented; the plain pawpaw butter was liked extremely by $26 \%$ of tasters; pawpaw butter prepared with lemon and grape juice was liked extremely by $11 \%$, while the version prepared with orange and lemon was liked extremely by only $8 \%$. Two versions of pawpaw custard were presented. The custard prepared from ripe, mild-flavored fruit was liked extremely by $42 \%$ of tasters, while the custard prepared from mixed under-ripe, over-ripe and bruised fruit was liked extremely by only $16 \%$. Ratings by persons unfamiliar with pawpaw flavor were significantly lower $(P<0.05)$ only for the two pawpaw custards; tasters age 40 years or younger gave significantly higher ratings for pawpaw ice cream $(P<0.05)$ and significantly lower ratings for both pawpaw custards (select, $P<0.05$ and mix, $P<$ $0.01)$ and the pawpaw/grape juice drink $(P<0.05)$.

The pawpaw is the largest fruit native to the United States (Darrow, 1975; Pomper et al., 1999). Pawpaw is a nutritionally superior fruit, being higher in some vitamins, minerals, and amino acids than in apple (Malus xsylvestris var. domestica), grape (Vitis spp.), and peach (Prunus persica) (Jones and Layne, 1997; Peterson et al., 1982). In some cultivars, there is a skin color change from green to green-yellow (e.g., 'PA-Golden \#l') when the fruit ripens. Flesh color of ripe fruit ranges from creamy white through bright yellow to shades of orange. The flavor of ripe pawpaw fruit resembles a combination of banana (Musa xparadisiaca), mango (Mangifera indica), and pineapple (Ananas comosus); however, flavor varies among cultivars, with some fruit displaying more complex flavor profiles. Ripe pawpaw fruit soften and have a powerful aroma (McGrath and Karahadian, 1994; Shiota, 1991). The flavor of a pawpaw fruit can intensify as it over-ripens, as with banana, resulting in pulp that is excellent for use in cooking. Usually the shelf life of a tree-ripened fruit stored at room temperature is 2 to 3 $\mathrm{d}$, but with refrigeration $\left[4^{\circ} \mathrm{C}\left(39.2^{\circ} \mathrm{F}\right)\right]$, fruit can be held up to 3 weeks while maintaining good eating quality (Layne, 1996).

This research was supported by U.S. Dept. of Agriculture, Cooperative State Research, Education, and Extension Service Agreements no. KYX-50-00-15H and KYX-10-97-28P to Kentucky State University.

${ }^{1}$ Human Nutrition Research, Atwood Research Facility, Kentucky State University, Frankfort, KY 40601. To whom reprint requests should be addressed.

${ }^{2}$ Horticulture Program, Atwood Research Facility, Kentucky State University, Frankfort, KY 40601-2355. 


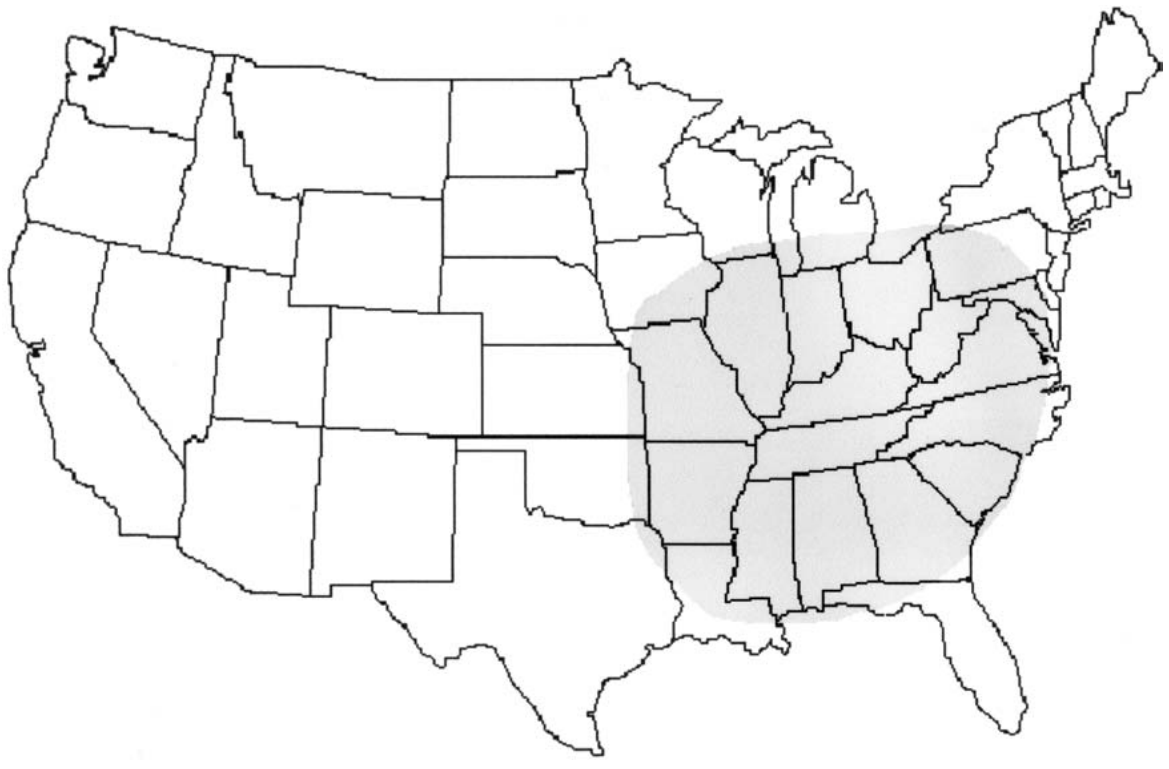

Fig. 1. Native range of the pawpaw.

As early as 1917, Langworthy and Holmes pointed out that the pawpaw fruit was little known outside of regions where it is found in the wild (Fig. 1), but the nutritional value of the fruit and its distinctive flavor made it worthy of further study. Because they ripen quickly and bruise easily, pawpaws are difficult to transport to market in an undamaged, saleable form (Layne, 1996; Peterson, 1991). Figure 2 illustrates the changes in appearance in a ripe pawpaw fruit stored at room temperature over a 4 -d period. While pawpaw enthusiasts may claim the taste improves as the discoloration expands, the shelf appeal of the Day-4 fruit in the eyes of the average shopper is questionable. However, there is commercial potential for pawpaw pulp, which can be extracted locally, stored and shipped frozen, then used as a flavoring in juices, ice cream, yogurt, baked goods, and other products. Such processed fruit products have a growing appeal to today's consumers. An important step in developing such products is to conduct taste tests to determine consumer acceptability (Jacobs, 1999; Pelletier, 2000). This taste test was conducted with a variety of food items in which pawpaw pulp was a key ingredient.

\section{Materials and methods}

SubJECTS. Attendees of the $2^{\text {nd }}$ Annual Pawpaw Field Day held in 1999 at the KSU Research and Demonstration Farm, Frankfort, Ky., were invited to taste eight pawpaw products. Of the grape juice, and butter with orange and lemon). Recipes for the cake, ice cream, and custard were based on those reported in the KSU Pawpaw Research Project publication Cooking with Pawpaws (Jones and Layne, 1997). The pawpaw ice cream was made by Bray Orchards, Bedford, Ky. The pawpaw butter/preserves were produced by a local jam maker (Robert Osborne, Somerset, Ky.). All items were made from frozen pulp, with the exception of the pawpaw butter/preserves, which were made with fresh pawpaw pulp. Participants were asked to taste each item and rate it on a scale from $1=$ liked it extremely to $7=$ disliked it extremely. Tasters were asked to take a sip of tepid water to clear their palate between tasting the items. The data set of responses was analyzed using SPSS 10.0 (SPSS Science, Chicago) to compute frequencies of scores; an analysis of variance procedure was used to determine significant differences in mean ratings between various groups.

\section{Results}

Table 1 shows pawpaw ice cream received the highest percent of "liked it extremely" ratings, followed by pawpaw cake with lemon icing. The custard prepared from ripe, mild-flavored fruit was more accepted than that prepared from fruits of mixed ripeness or bruised fruit. Of the three alternative recipes for pawpaw butter presented, the plain pawpaw butter was most liked, pawpaw butter, butter with lemon and
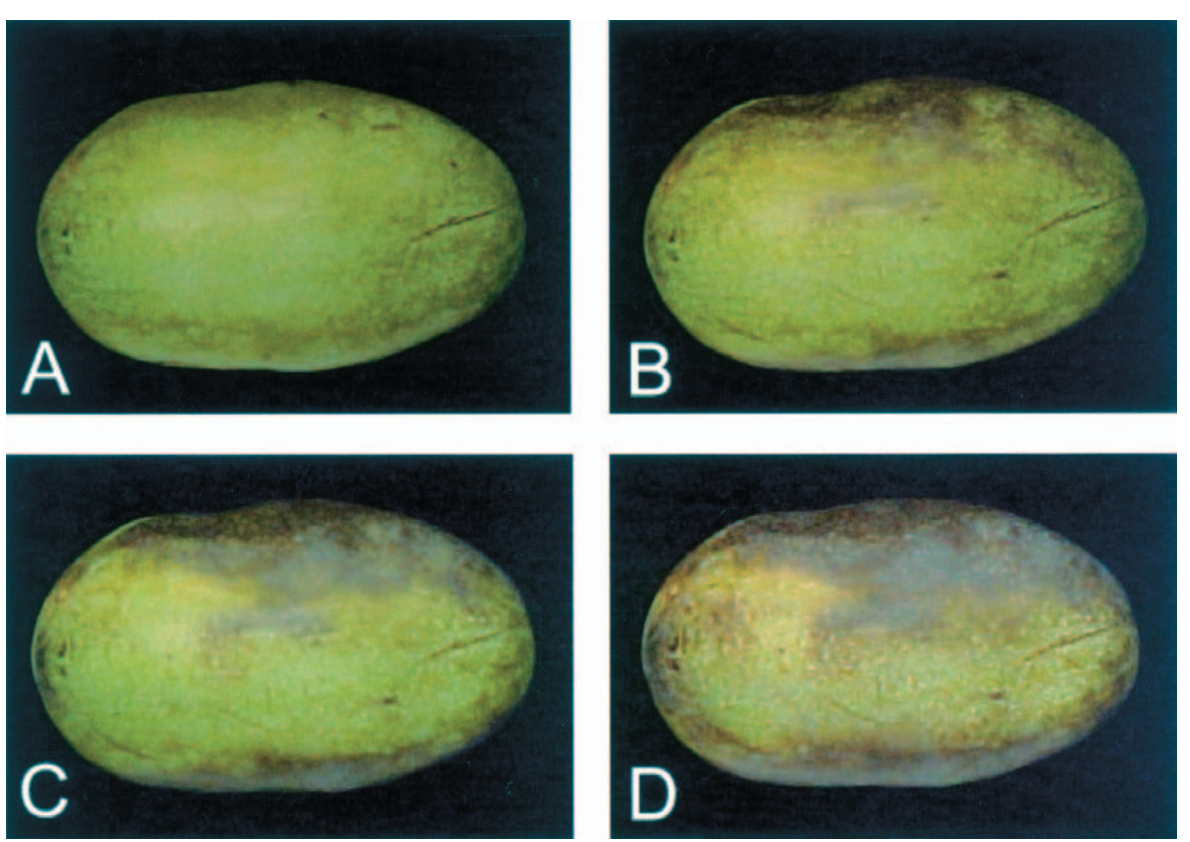

Fig. 2. Appearance changes in pawpaw fruit stored at room temperature over a 4-d period. 
Table 1. Percentage of individuals responding on a scale of 1 to $7^{\mathrm{z}}$ after tasting various products flavored with pawpaw.

\begin{tabular}{|c|c|c|c|c|c|c|c|c|}
\hline \multirow[b]{3}{*}{ Item } & \multirow[b]{3}{*}{$\mathbf{N}^{\mathrm{y}}$} & \multicolumn{7}{|c|}{ Responses (\%) } \\
\hline & & \multicolumn{2}{|c|}{$\begin{array}{l}\text { Liked it } \\
\text { extremely }\end{array}$} & \multicolumn{3}{|c|}{$\begin{array}{l}\text { Neither liked } \\
\text { nor disliked }\end{array}$} & \multicolumn{2}{|c|}{$\begin{array}{l}\text { Disliked it } \\
\text { extremely }\end{array}$} \\
\hline & & 1 & 2 & 3 & 4 & 5 & 6 & 7 \\
\hline Pawpaw ice cream & 98 & 55.1 & 28.6 & 13.3 & 3.1 & --- & --- & --- \\
\hline Pawpaw cake with lemon icing & 95 & 45.3 & 28.4 & 20.0 & 4.2 & 2.1 & -.- & -.- \\
\hline Pawpaw custard from ripe fruit & 95 & 42.1 & 33.7 & 13.7 & 6.3 & 2.1 & --- & 2.1 \\
\hline Grape/pawpaw juice & 103 & 31.1 & 33.0 & 20.4 & 10.7 & 3.9 & --- & 1.0 \\
\hline Plain pawpaw butter & 97 & 25.8 & 39.2 & 24.7 & 8.2 & 2.1 & --- & --- \\
\hline Pawpaw custard from mixed ripeness fruit & 93 & 16.1 & 43.0 & 26.9 & 5.4 & 6.5 & --- & 2.2 \\
\hline Pawpaw butter with lemon and grape juice & 100 & 11.0 & 36.0 & 37.0 & 10.0 & 4.0 & 1.0 & 1.0 \\
\hline Pawpaw butter with orange and lemon & 97 & 8.2 & 25.8 & 30.9 & 18.6 & 9.3 & 6.2 & 1.0 \\
\hline
\end{tabular}

${ }^{2}$ Taste was rated from 1 to 7 , with $1=$ liked extremely and $7=$ disliked extremely.

yThe number of valid responses from individuals for each item.

Table 2. Taste ratings for products flavored with pawpaw by all participants, by age classifications, and by previous pawpaw consumption.

\begin{tabular}{|c|c|c|c|c|c|}
\hline & \multicolumn{5}{|c|}{ Rating $^{z}$} \\
\hline & \multirow[b]{2}{*}{$\begin{array}{c}\text { All } \\
\text { participants }\end{array}$} & \multicolumn{2}{|c|}{ Age (years) } & \multicolumn{2}{|c|}{ Tasted pawpaw before } \\
\hline & & $\begin{array}{c}\leq 40 \\
\mathrm{n}=22\end{array}$ & $\begin{array}{c}\geq 41 \\
\mathrm{n}=71\end{array}$ & $\begin{array}{c}\text { Yes } \\
\mathrm{n}=69\end{array}$ & $\begin{array}{c}\text { No } \\
\mathrm{n}=27\end{array}$ \\
\hline Pawpaw ice cream & $1.65 \pm 0.82$ & $1.30 \pm 0.57$ & $1.72 \pm 0.84^{*}$ & $1.66 \pm 0.80$ & $1.50 \pm 0.63$ \\
\hline Pawpaw cake with lemon icing & $1.91 \pm 1.02$ & $1.86 \pm 1.28$ & $1.94 \pm 0.93$ & $1.79 \pm 0.85$ & $2.24 \pm 1.29$ \\
\hline Pawpaw custard from ripe fruit & $1.94 \pm 1.19$ & $2.38 \pm 1.77$ & $1.75 \pm 0.89^{*}$ & $1.80 \pm 0.92$ & $2.50 \pm 1.66^{*}$ \\
\hline Plain pawpaw butter & $2.18 \pm 0.99$ & $2.19 \pm 1.21$ & $2.20 \pm 0.93$ & $2.24 \pm 1.05$ & $2.16 \pm 0.89$ \\
\hline Grape/pawpaw juice & $2.28 \pm 1.25$ & $2.77 \pm 1.60$ & $2.13 \pm 1.11^{*}$ & $2.22 \pm 1.17$ & $2.41 \pm 1.41$ \\
\hline Pawpaw custard from mixed ripeness fruit & $2.47 \pm 1.22$ & $3.15 \pm 1.73$ & $2.27 \pm 0.97^{\star \star}$ & $2.33 \pm 1.04$ & $3.09 \pm 1.65^{*}$ \\
\hline Pawpaw butter with lemon and grape juice & $2.70 \pm 1.11$ & $3.05 \pm 1.53$ & $2.57 \pm 0.90$ & $2.74 \pm 1.23$ & $2.64 \pm 0.74$ \\
\hline Pawpaw butter with orange and lemon & $3.19 \pm 1.35$ & $3.34 \pm 1.52$ & $3.14 \pm 1.25$ & $3.22 \pm 1.28$ & $3.32 \pm 1.57$ \\
\hline
\end{tabular}

${ }^{2}$ Rating: 1 = liked it extremely to 7 = disliked it extremely; ( \pm standard deviation).

*** Significantly different from column directly on the left at $P<0.05$ or 0.01 .

followed by pawpaw butter prepared with lemon and grape juice; the version prepared with orange and lemon was least liked. Table 2 presents rating scores for each item $($ mean $\pm \mathrm{SD})$ for all participants, by two age classifications, and by previous consumption of pawpaw products. Comparisons of mean ratings by gender showed no significant differences, and are not reported here. Pawpaw ice cream received slightly but significantly greater acceptance by participants age 40 years or younger, while both pawpaw custards and the grape/pawpaw juice drink were significantly more accepted by participants over 40 years. Both pawpaw custards received significantly less acceptance from those who had not eaten pawpaw previously. While it might be expected that a relationship existed between age and previous pawpaw consumption, analysis of the response data showed no significant interaction. The mean age of those who had tasted pawpaw previously was 49 years; for those who had not tasted pawpaw before the mean age was 48 years. Seventy-three percent of participants age 40 years or younger had tasted pawpaws previously and $73 \%$ of participants over 40 years had previously tasted pawpaws.

\section{Discussion}

Familiarity often influences children's food preferences, and nutritional beliefs and health attitudes can impact food choices made by adults. Regardless of age, however, taste is the primary influence on food choices made by consumers (Drewnowski, 1997). Overall, these tasters reported favorable response to the pawpaw products tested. Their acceptance of these processed fruit products indicates a broader outlet exists for pawpaw beyond fresh fruit and the local market.

While it might be suspected that individuals attending a pawpaw field day were pre-disposed to give favorable evaluations on pawpaw products, our analysis of responses found previous consumption of pawpaw actually had limited impact on the ratings given to most products. Only for the two pawpaw custards did tasters who had not previously consumed pawpaws give significantly lower ratings. Because the custard had a strong pawpaw flavor, these lower ratings suggest that unfamiliarity negatively affected acceptance. Tasters may also have found the over-ripe fruit flavor unappealing. One approach to determining this influence would be to hold repeat tastings to learn if rating scores improve with exposure. A second limitation of this study was the lack of diversity among tasters. Additional taste tests should be conducted with target audiences to determine how ethnicity and age influence acceptance. Data was not collected on the ethnic background of participants; however, the attendees were predominately Caucasian. These findings suggested that age influenced acceptance, however, the subjects were primarily adults. As the field day was held on a weekday during the school year, only two children were in attendance. When evaluating acceptance of food items, participants are usually asked to rate items on several organoleptic traits: appearance, texture, flavor, etc. (Beany and Stoffella, 1998; Pelletier, 2000). Because of the limited time allowed 
and numerous items presented, the rating form for this tasting measured only overall acceptance. Future tastings could focus on fewer items, incorporate the evaluation of various taste factors, and use trained tasters to ensure reliable responses.

\section{Literature cited}

Beany, A.H. and P.J. Stoffella. 1998. Spaghetti squash. 30 Nov. 2001. <http: //irrec.ifas.ufl.edu/Research/spaghetti_ squash.htm>.

Darrow, G.M. 1975. Minor temperate fruits, p. 276-277. In: J. Janick and J.N. Moore (eds.). Advances in fruit breeding. Purdue Univ. Press, West Lafayette, Ind.

Drewnowski, A. 1997. Taste preferences and food intake. Annu. Rev. Nutr. 17: 237-53.
Jacobs, D. 1999. Pitaya (Hylocereus undatus), a potential new crop for Australia. Austral. New Crops Nwsltt. January 1999. 30 Nov. 2001. <http: //www.newcrops.uq.edu.au/newslett/ nenl 1163.htm>.

Jones, S.C. and D.R. Layne. 1997. Cooking with pawpaws. Kentucky State University Cooperative Extension Program, Bulletin \#PIB-001.

Langworthy, C.F. and A.D. Holmes. 1917. The American papaw and its food value. J. Home Econ. 9:39-45.

Layne, D.R. 1996. The pawpaw [Asimina triloba (L.) Dunal.]: A new fruit crop for Kentucky and the United States. HortScience 31:777-784.

McGrath, M.J. and C. Karahadian. 1994. Evaluation of physical, chemical, and sensory properties of pawpaw fruit (Asimina triloba) as indicators of ripeness. J. Agr. Food Chem. 42:968-974
Pelletier, A. 2000. Business basics for Alberta food processors: A planning guide. 30 Nov. 2001. <http: //www.agric.gov.ab.ca/food/process/ guide/planningguide 08 .html>

Peterson, R.N., J.P. Cherry, and J.G. Simmons. 1982. Composition of pawpaw (Asimina triloba) fruit. Annu. Rpt. N. Nut Growers Assn. 73:97-106.

Peterson, R.N. 1991. Pawpaw (Asimina). Acta Hort. 290:567-600

Pomper, K.W., D.R. Layne, and R.N. Peterson. 1999. The pawpaw regional variety trial, p. 353-357. In J. Janick (ed.). Perspectives on new crops and new uses. ASHS Press, Alex., Va.

Shiota, H. 1991.Volatile components of pawpaw fruit (Asimina triloba Dunal.) J. Agr. Food Chem. 39:1631-1635. 